\title{
Priming of Long-Term Potentiation in Mouse Hippocampus by Corticotropin-Releasing Factor and Acute Stress: Implications for Hippocampus-Dependent Learning
}

\author{
Thomas Blank, ${ }^{*}$ Ingrid Nijholt, ${ }^{*}$ Klaus Eckart, and Joachim Spiess \\ Department of Molecular Neuroendocrinology, Max-Planck Institute for Experimental Medicine, \\ D-37075 Goettingen, Germany
}

In the present experiments, we characterized the action of human/rat corticotropin-releasing factor (h/rCRF) and acute stress ( $1 \mathrm{hr}$ of immobilization) on hippocampus-dependent learning and on synaptic plasticity in the mouse hippocampus. We first showed that $\mathrm{h} / \mathrm{rCRF}$ application and acute stress facilitated (primed) long-term potentiation of population spikes (PSLTP) in the mouse hippocampus and enhanced contextdependent fear conditioning. Both the priming of PS-LTP and the improvement of context-dependent fear conditioning were prevented by the CRF receptor antagonist [Glu ${ }^{11,16}$ ]astressin. PS-LTP priming and improved learning were also reduced by the protein kinase $\mathrm{C}$ inhibitor bisindolylmaleimide I. Acute stress induced the activation of $\mathrm{Ca}^{2+} /$ calmodulin-dependent kinase II (CaMKII) $2 \mathrm{hr}$ after the end of the stress session. The
CaMKII inhibitor KN-62 antagonized the stress-mediated learning enhancement, however, with no effect on PS-LTP persistence. Thus, long-lasting increased neuronal excitability as reflected in PS-LTP priming appeared to be essential for the enhancement of learning in view of the observation that inhibition of PS-LTP priming was associated with impaired learning. Conversely, it was demonstrated that inhibition of CaMKII activity reduced contextual fear conditioning without affecting PS-LTP priming. This observation suggests that priming of PS-LTP and activation of CaMKII represent two essential mechanisms that may contribute independently to long-term memory.

Key words: priming; neuronal excitability; h/rCRF; CaMKII; LTP; PKC; classical fear conditioning
Corticotropin-releasing factor (CRF) is a 41-amino acid neuropeptide that is synthesized in the hypothalamus and mediates the release of adrenocorticotropic hormone from the anterior pituitary (Spiess et al., 1981; Vale et al., 1981). The anatomic distribution of CRF in the brain suggests that this peptide not only stimulates the release of corticotropin from the pituitary but also may modulate the neuronal activity of various other brain areas (De Souza et al., 1985; Chang et al., 1993; Potter et al., 1994; Chalmers et al., 1995). CRF has been shown to modulate learning, food intake, arousal, startle and fear responses, general motor activity, body temperature, and sexual activity (Heinrichs et al., 1995; Buwalda et al., 1997; Holahan et al., 1997; Linthorst et al., 1997; Radulovic et al., 1999). Exogenous application of CRF to hippocampal slices reduces the slow afterhyperpolarization and spike frequency accommodation (Aldenhoff et al., 1983; Haug and Storm, 2000) and enhances the amplitude of CA1 population spikes evoked by stimulation of the Schaffer collateral pathway in rats (Hollrigel et al., 1998). Recent studies have demonstrated that CRF produces a long-lasting enhancement of synaptic efficacy in the rat hippocampus in vivo (Wang et al., 1998, 2000). CRF has also been implicated in learning in view of the observation that $\mathrm{CRF}$ injection into the mouse hippocampus a few minutes before training enhances classical fear conditioning sig-

\footnotetext{
Received Oct. 29, 2001; revised Jan. 11, 2002; accepted Jan. 25, 2002.

This work was supported by the Max Planck Society. We are grateful to Thomas Liepold and Hossein Tezval for amino acid analysis and peptide synthesis. We thank Stefanie Vollstädt for excellent technical assistance.

*T.B. and I.N. contributed equally to this work.

Correspondence should be addressed to Thomas Blank, Department of Molecular Neuroendocrinology, Max Planck Institute for Experimental Medicine, HermannRein-Strasse 3, D-37075 Goettingen, Germany. E-mail: blank@mail.em.mpg.de. Copyright (C) 2002 Society for Neuroscience 0270-6474/02/223788-07\$15.00/0
}

nificantly (Radulovic et al., 1999). When injected directly into the dentate gyrus of the hippocampus, CRF improves the retention of one-way inhibitory avoidance learning in rats (Lee et al., 1992). However, no electrophysiological studies on the function of CRF in the mouse hippocampus have been performed to date.

The following series of experiments were aimed at further defining the effect of acute stress and human/rat CRF (h/rCRF) on hippocampus-dependent learning and on long-term synaptic plasticity in the mouse hippocampus. In view of the possibility that acute stress can induce changes in thresholds for synaptic plasticity necessary for long-term potentiation (LTP) induction (Foy et al., 1987; Kim et al., 1996; Kim and Yoon, 1998), which has been referred to as "metaplasticity" (Abraham and Bear, 1996), we investigated the effects of $\mathrm{h} / \mathrm{rCRF}$ and immobilization stress on the induction and persistence of LTP of population spikes (PS-LTP). The threshold for hippocampus-dependent synaptic plasticity and memory storage is thought to be determined by protein phosphorylation (Huang, 1998). In particular, activation of protein kinase C (PKC) (Wang and Feng, 1992), $\mathrm{Ca}^{2+} /$ calmodulin-dependent kinase II (CaMKII) (Malenka et al., 1989), or both (Malinow et al., 1989) has been suggested to be indispensable for induction of excitatory postsynaptic field potential (fEPSP)-LTP in the hippocampal CA1 region. Thus, we assessed the roles of PKC and CaMKII in the regulation of hippocampal long-term synaptic plasticity and in the performance of mice in a hippocampus-dependent learning task.

\section{MATERIALS AND METHODS}

Animals. Experiments were performed on 9- to 12-week-old male BALB/c mice (Charles River, Sultzfeld, Germany). The mice were individually housed and maintained on a $12 \mathrm{hr}$ light/dark cycle (lights on 
at 7 A.M.) with access to food and water ad libitum. All experimental procedures were in accordance with the European Council Directive (86/609/EEC) by permission of the Animal Section Law enforced by the District Government of Braunschweig (Lower Saxony, Germany).

Hippocampal slice electrophysiology. Mice were briefly anesthetized with isoflurane and then decapitated. In $<1 \mathrm{~min}$, the skull was opened, and the brain was removed and transferred to ice-cold artificial CSF (aCSF) solution of the following composition (in $\mathrm{mm}$ ): $130 \mathrm{NaCl}, 3.5$ $\mathrm{KCl}, 1.25 \mathrm{NaH}_{2} \mathrm{PO}_{4}, 1.5 \mathrm{MgSO}_{4}, 2 \mathrm{CaCl}_{2}, 24 \mathrm{NaHCO}_{3}$, and 10 glucose, equilibrated with $95 \% \mathrm{O}_{2} / 5 \% \mathrm{CO}_{2}, \mathrm{pH} 7.4$. Hippocampi were dissected from the chilled brain hemispheres on ice. Transverse hippocampal slices $(400 \mu \mathrm{m})$ were obtained on a McIlwain tissue chopper (The Mickle Laboratory Engineering Co. Ltd., Surrey, UK) and kept submerged (minimum of $1 \mathrm{hr}$ at room temperature before recordings) in aCSF. Extracellular field potentials were recorded in a recording chamber maintained at $32^{\circ} \mathrm{C}$ with recording electrodes pulled from borosilicate glass and filled with $2 \mathrm{M} \mathrm{NaCl}(3-5 \mathrm{~m} \Omega)$. All recordings were made using a SEC-05L amplifier (npi Electronics, Tamm, Germany). To record field potentials in the CA1 pyramidal cell body layer, Schaffer collaterals were stimulated with a bipolar electrode placed on the surface of the slice. At the beginning of each experiment, a stimulus-response curve was established by increasing the stimulus intensity and measuring the amplitude of the population spike. On the basis of the input-output function, the stimulus was adjusted to elicit a population spike with an amplitude of half maximum and was fixed at this level throughout the experiments. PS-LTP was induced by theta burst stimulation (TBS) at the test pulse intensity, consisting of $5 \times 100 \mathrm{~Hz}$ bursts (five diphasic pulses per burst) with a $200 \mathrm{msec}$ interburst interval. Traces were stored on a computer using Pulse 7.4 software (Heka, Lambrecht, Germany) for off-line analysis. Short-term potentiation (STP) and PS-LTP were measured 5 and 60 min after tetanic stimulation, respectively.

Cannulation. Double-guide cannulas (C235; Plastics One, Roanoke, VA) were implanted using a stereotactic holder during $1.2 \%$ avertin anesthesia $(0.02 \mathrm{ml} / \mathrm{gm}$, i.p.) under aseptic conditions as described previously (Radulovic et al., 1999; Stiedl et al., 2000). Each double-guide cannula with inserted dummy cannula and dust cap was fixed to the skull with dental cement. The cannulas were placed into both lateral brain ventricles, with anteroposterior (AP) coordinates zeroed at bregma (AP, $0 \mathrm{~mm}$; lateral, $1 \mathrm{~mm}$; depth, $3 \mathrm{~mm}$ ) or directed toward both dorsal hippocampi (AP, $-1.5 \mathrm{~mm}$; lateral, $1 \mathrm{~mm}$; depth, $2 \mathrm{~mm}$ ) (Franklin and Paxinos, 1997). The animals were allowed to recover for $4-5 \mathrm{~d}$ before the experiments started. On the day of the experiment, bilateral injections were performed using an infusion pump (CMA/100; CMA Microdialysis, Solna, Sweden) at a constant rate of $0.33 \mu \mathrm{l} / \mathrm{min}$ (final volume, 0.25 $\mu \mathrm{l} /$ side). Cannula placement was verified post hoc in all mice by injection of methylene blue dye. For electrophysiological experiments, doubleguide cannula placement was verified by unilateral methylene blue injection. We never observed any effects of cannulation itself or vehicle injection.

Drugs. h/rCRF (Rühmann et al., 1996) and [Glu ${ }^{11,16}$ ]astressin (Eckart et al., 2001) were synthesized in our laboratory as described. KN-62 and bisindolylmaleimide I (BIS-I) were from Calbiochem (San Diego, CA).

Drug treatment. $\left[\right.$ Glu $\left.^{11,16}\right]$ astressin was dissolved in aCSF solution. $\mathrm{h} / \mathrm{rCRF}$ stock solutions were prepared in $10 \mathrm{~mm}$ acetic acid. Final dilutions in aCSF to $400 \mathrm{ng} / \mu \mathrm{l}$ were prepared immediately before the experiments. The final $\mathrm{pH}$ of the peptide solution was 7.4. KN-62 was dissolved in DMSO to a concentration of $4 \mathrm{mg} / \mathrm{ml}$. For injection, the stock was diluted in aCSF to a final concentration of $64 \mathrm{ng} / \mu \mathrm{l}$. BIS-I was stored as $1 \mathrm{~mm}$ stock solution in DMSO. For injection, the solution was diluted with aCSF to a final concentration of $0.4 \mathrm{nmol} / \mu \mathrm{l}$. DMSO in the concentrations used did not exhibit any significant effect by itself on synaptic responses or learning.

Immobilization stress. An acute immobilization stress of mice consisted of taping their limbs to a plastic surface for $1 \mathrm{hr}$ (Smith et al., 1995).

Fear conditioning. The fear-conditioning experiments were performed as described previously (Stiedl et al., 2000) using a computer-controlled fear-conditioning system (TSE, Bad Homburg, Germany). Fear conditioning was performed in a Plexiglas cage $(36 \times 21 \times 20 \mathrm{~cm})$ within a fear-conditioning box that was constantly illuminated $(12 \mathrm{~V}, 10 \mathrm{~W}$ halogen lamp, 100-500 lux). In the conditioning box, a high-frequency loudspeaker (KT-25-DT; Conrad, Hirschau, Germany) provided constant background noise [white noise, $68 \mathrm{~dB}$ sound pressure level (SPL)]. The training (conditioning) consisted of a single trial. The mouse was exposed to the conditioning context $(180 \mathrm{sec})$, followed by a tone [conditioned stimulus (CS), $30 \mathrm{sec}, 10 \mathrm{kHz}, 75 \mathrm{~dB}$ SPL, pulsed $5 \mathrm{~Hz}$. After termination of the tone, a foot shock [unconditioned stimulus (US), 0.7 $\mathrm{mA}, 2 \mathrm{sec}$, constant current] was delivered through a stainless steel grid floor. The mouse was removed from the fear-conditioning box $30 \mathrm{sec}$ after shock termination to avoid an aversive association with the handling procedure. Under these conditions, the context served as background stimulus. Background contextual fear conditioning but not foreground contextual fear conditioning, in which the tone is omitted during training, has been shown to involve the hippocampus (Phillips and LeDoux, 1994). Memory tests were performed $24 \mathrm{hr}$ after fear conditioning. Contextual memory was tested in the fear-conditioning box for $180 \mathrm{sec}$ without CS or US presentation (with background noise). Freezing, defined as the lack of movement except for respiration and heart beat, was assessed as the behavioral parameter of the defensive reaction of mice (Blanchard and Blanchard, 1969; Bolles and Riley, 1973; Fanselow and Bolles, 1979) by a time-sampling procedure every $10 \mathrm{sec}$ throughout memory tests. In addition, activity-derived measures (inactivity, mean activity, and exploratory area) were recorded by a photo-beam system $(10 \mathrm{~Hz}$ detection rate) controlled by the fear-conditioning system.

Western blotting. Hippocampal slices were prepared as described above. CA1 subregions of hippocampal slices were dissected out and immediately homogenized at $4^{\circ} \mathrm{C}$ with a plastic homogenizer in homogenization buffer containing $50 \mathrm{~mm}$ Tris-HCl, pH 8.0, 10 mm EDTA, 4 mM EGTA, $15 \mathrm{~mm}$ sodium phosphate, $100 \mathrm{~mm} \beta$-glycerophosphate, $10 \mathrm{~mm}$ sodium fluoride, $2 \mu \mathrm{g} / \mathrm{ml}$ aprotinin, $2 \mu \mathrm{g} / \mathrm{ml}$ leupeptin, $0.7 \mu \mathrm{g} / \mathrm{ml}$ pepstatin, and $1 \mathrm{~mm}$ phenylmethylsulfonyl fluoride, $\mathrm{pH}$ 7.4. The insoluble material was removed by centrifugation at $15,000 \times g$ for $10 \mathrm{~min}$ at $4^{\circ} \mathrm{C}$. Protein concentrations were determined with a Bradford assay (Bio-Rad, Munich, Germany). Equal amounts of protein for each group were separated on a $10 \%$ SDS gel and transferred to an Immobilon-P membrane (Millipore, Bedford, MA) using a semidry transfer apparatus. The blot was probed using an anti-active CaMKII antibody (Promega, Madison, WI) or antibody directed against total CaMKII (Chemicon, Temecula, CA) and detected with horseradish peroxidase-conjugated second antibody. Western blots were developed using the chemiluminescence method.

Statistics. Statistical comparisons were made using Student's $t$ test and ANOVA. Data were expressed as mean \pm SEM. Significance was determined at the level of $p<0.05$.

\section{RESULTS}

\section{Activation of CRF receptors primes PS-LTP}

Using intracellular recordings, we have found previously that $\mathrm{h} / \mathrm{rCRF}$ increased pyramidal cell excitability in the hippocampal CA1 area of BALB/c mice, primarily via activation of the PKC pathway (T. Blank and I. Nijholt, unpublished observations). In the present experiments, population spikes were recorded in the stratum pyramidale of the CA1 subfield to investigate how the $\mathrm{h} / \mathrm{rCRF}$-induced increase in cell excitability affects PS-LTP induction and persistence. Bath application of $\mathrm{h} / \mathrm{rCRF}$ transiently enhanced population spike amplitudes, which returned to near baseline during the 30 min washout period (Fig. 1A). The maximal increase in population spike amplitudes was significant compared with control responses before drug application (154 $\pm 25 \%$; $n=8 ; p<0.05)$. After $\mathrm{h} / \mathrm{rCRF}$ treatment, weak TBS resulted in enhanced PS-LTP persistence compared with controls (200 \pm 23\%; $n=8 ; p<0.05$ ) (Fig. $1 A$ ). However, h/rCRF treatment did not exhibit any significant effect on STP $(236 \pm 20 \% ; n=8)$ compared with controls $(214 \pm 29 \% ; n=5)($ Fig. $1 A)$. The CRF receptor antagonist [Glu ${ }^{11,16}$ ] astressin prevented the $\mathrm{h} / \mathrm{rCRF}$ mediated transient increase in synaptic transmission $(102 \pm 5 \%$; $n=5 ; p<0.05)$, attenuated STP $(156 \pm 23 \% ; n=5 ; p<0.05)$ compared with h/rCRF-treated slices $(236 \pm 20 \% ; n=8)$, and abolished the priming effect (PS-LTP measured $1 \mathrm{hr}$ after induction: $107 \pm 10 \% ; n=5)($ Fig. $1 B)$. [Glu $\left.{ }^{11,16}\right]$ astressin specifically blocked the priming effect of $\mathrm{h} / \mathrm{rCRF}$, as demonstrated by the finding that it did not significantly affect STP $(205 \pm 7 \% ; n=5)$ or PS-LTP $(127 \pm 12 \% ; n=5)$ when applied by itself. 
A

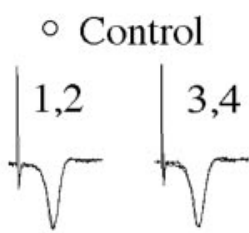

- $\mathrm{h} / \mathrm{r} \mathrm{CRF}(125 \mathrm{nM})$

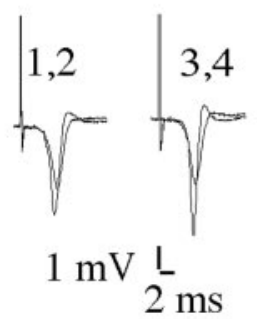

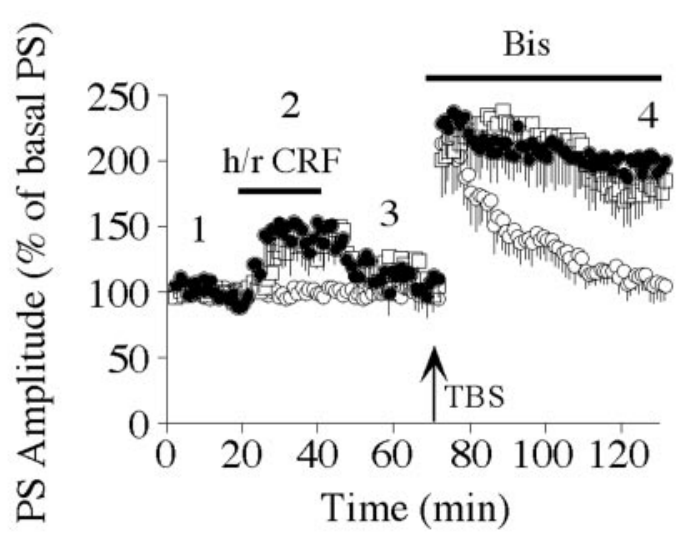

B

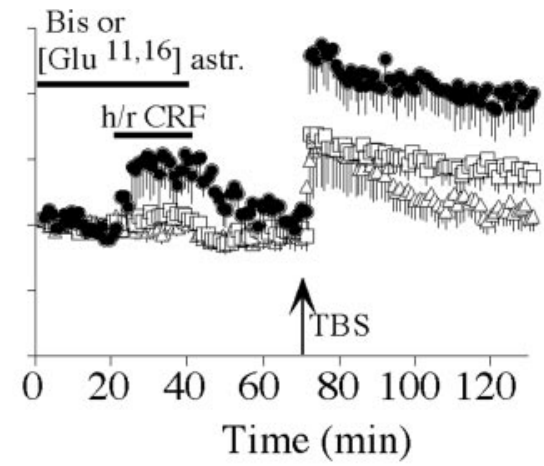

Figure 1. $\mathrm{h} / \mathrm{rCRF}-$ mediated facilitation of PS-LTP persistence is prevented by the inhibition of CRF receptors and PKC. A, Left, Representative recordings performed before (1), during (2), and after (3) h/rCRF application and $1 \mathrm{hr}$ after tetanus (4). Traces represent the average of six recordings. Right, A $20 \mathrm{~min} \mathrm{h/rCRF}$ application (125 nM; $)$ transiently increased population spike amplitudes and subsequently enhanced the persistence of PS-LTP induced by TBS compared with controls $(\bigcirc)$. The selective PKC inhibitor BIS-I $(1,2 \mu \mathrm{M} ; \square)$ was bath-applied for the rest of the experiment. This treatment had no effect on PS-LTP persistence. $B$, Preincubation of slices with BIS-I $(1,2 \mu \mathrm{M} ; \square)$ for 1 hr markedly prevented the h/rCRF-mediated increase $(125 \mathrm{nM} ; 0)$ of population spike amplitudes and subsequent priming of hippocampal PS-LTP. Preincubation of slices with the CRF receptor antagonist [Glu ${ }^{11,16}$ ] astressin $(500 \mathrm{nM} ; \triangle)$ for $40 \mathrm{~min}$ completely blocked the $\mathrm{h} / \mathrm{rCRF}$-mediated increase of population spike amplitudes and the facilitation of TBS-induced PS-LTP. Data are presented as mean \pm SEM.

Figure 2. Inhibition of $\mathrm{PKC}$ and $\mathrm{CRF}$ receptors but not of CaMKII prevents stress-mediated facilitation of LTP maintenance in the hippocampal CA1 area. $A$, TBS-induced PS-LTP in slices prepared from nonstressed animals $(\bullet)$ and in slices prepared $2 \mathrm{hr}$ after exposure of the animal to $1 \mathrm{hr}$ of immobilization $(\bigcirc)$. $B$, TBSinduced PS-LTPs from animals that were injected intracerebroventricularly with KN-62 $(\diamond)$, BIS-I $(\square)$, or $\left[\mathrm{Glu}^{11,16}\right] \operatorname{astressin}(\mathbf{\Delta})$ immediately before $1 \mathrm{hr}$ of immobilization. Hippocampal slices were prepared $2 \mathrm{hr}$ after the end of the stress session. Data are presented as mean \pm SEM.
A

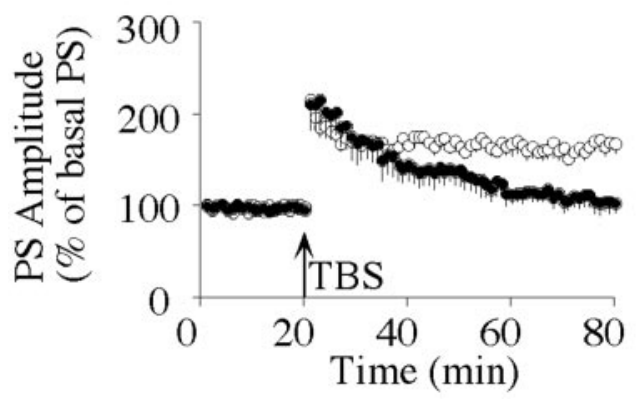

B

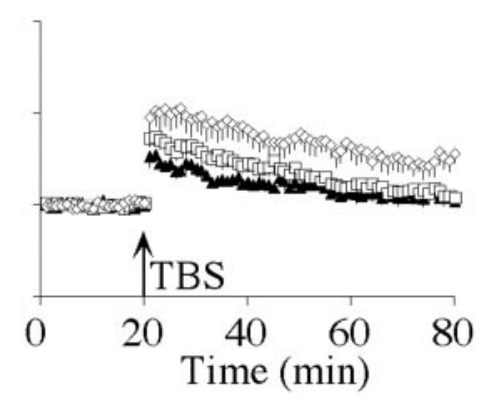

\section{Contribution of PKC to the PS-LTP priming effect of $h / r C R F$}

We subsequently investigated whether the PKC inhibitor BIS-I (Toullec et al., 1991) could antagonize the increase in synaptic transmission and the subsequent PS-LTP priming observed after $\mathrm{h} / \mathrm{rCRF}$ application. After $1 \mathrm{hr}$ of preincubation in aCSF containing $1.2 \mu \mathrm{M}$ BIS-I, population spikes were no longer significantly potentiated after exposure to $\mathrm{h} / \mathrm{rCRF}$ in the presence of BIS-I $(104 \pm 8 \% ; n=5)$ (Fig. $1 B)$. BIS-I also reduced STP $(163 \pm 13 \% ; n=5 ; p<0.05)$ (Fig. $1 B)$ compared with STP after $\mathrm{h} / \mathrm{rCRF}$ application $(236 \pm 20 \% ; n=8)($ Fig. $1 B)$ and impaired the subsequent PS-LTP $(137 \pm 13 \% ; n=5)$ (Fig. $1 B)$, which was not significantly different from the values of control experiments $(105 \pm 11 \% ; n=5)$ (Fig. $1 A)$. Preincubation of BIS-I without subsequent application of $\mathrm{h} / \mathrm{rCRF}$ did not exhibit any significant effect on STP $(225 \pm 24 \% ; n=5)$ or PS-LTP $(117 \pm 18 \% ; n=$ 5) compared with controls. When BIS-I was applied to h/rCRF treated slices for $1 \mathrm{hr}$ immediately after the TBS, it did not significantly affect the persistence of PS-LTP $(185 \pm 12 \% ; n=6)$ (Fig. 1A) compared with PS-LTP induced in slices that were exposed to $\mathrm{h} / \mathrm{rCRF}$ alone (Fig. $1 A, B)$.

\section{Acute stress and PS-LTP priming}

Because CRF was shown to play an important role as a mediator of stress responses in the brain (for review, see Turnbull and Rivier, 1997; Eckart et al., 1999; Koob and Heinrichs, 1999), we subsequently investigated whether acute behavioral stress influences the persistence of hippocampal PS-LTP induced by weak TBS. When hippocampal brain slices were prepared $2 \mathrm{hr}$ after immobilization, a significantly higher degree of PS-LTP was observed than in controls $(175 \pm 12 \% ; n=6 ; p<0.05)$ (Fig. $2 A)$. There was no difference in STP between recordings from control animals $(205 \pm$ $22 \% ; n=5)$ and stressed animals $(188 \pm 9 \% ; n=6)($ Fig. $2 A)$. To determine whether stress-mediated priming required the activation of CRF receptors or PKC, [Glu ${ }^{11,16}$ ] astressin or BIS-I was injected intracerebroventricularly immediately before the stress session. Recordings from slices obtained $2 \mathrm{hr}$ after immobilization revealed that $\left[\mathrm{Glu}^{11,16}\right]$ astressin $(104 \pm 6 \% ; n=5)$ and BIS-I $(108 \pm 7 \%$; $n=5$ ) (Fig. $2 B$ ) had completely blocked the persistence of PSLTP. These values were not significantly different from those of nonstressed controls (Fig. $2 A$ ). In addition, STP was significantly attenuated in slices from stressed animals after injection of $\left[\mathrm{Glu}^{11,16}\right]$ astressin $(140 \pm 5 \% ; n=5 ; p<0.05)$ (Fig. $\left.2 B\right)$. Western 
A

\section{P-Thr 286 CaMKII}

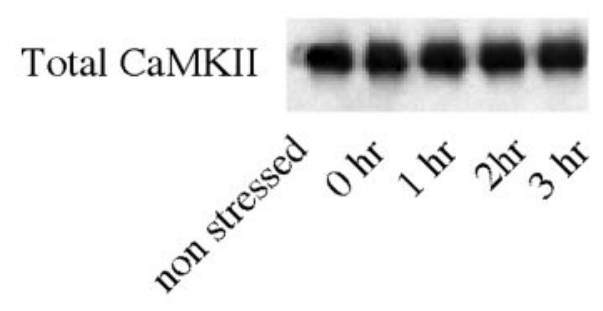

\section{B}

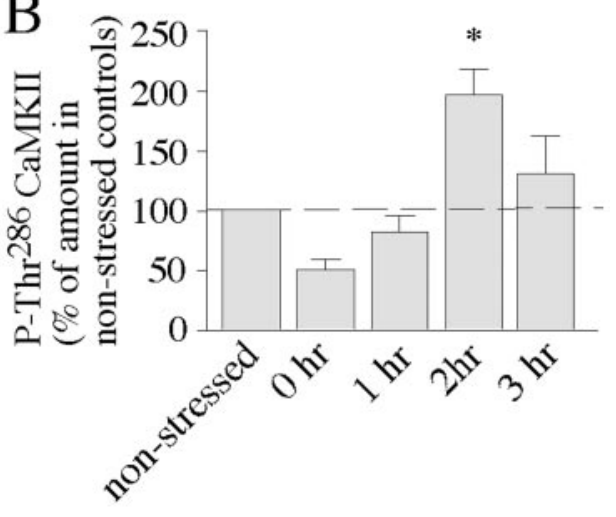

Figure 3. Acute stress induces activation of CaMKII in the hippocampal CA1 area. $A$, CA1 homogenates dissected from animals at several time points after $1 \mathrm{hr}$ of immobilization were probed with an antibody specific for $\mathrm{Thr}^{286}$-phosphorylated CaMKII or an antibody recognizing total CaMKII. Nonstressed mice are shown as controls. Results are representative of four independent Western blots. $B$, The bar graph summarizes Western blot data of four experiments and shows the levels of $\mathrm{Thr}^{286}$-phosphorylated CaMKII expressed as a percentage of nonstressed controls. The dashed line represents the normalized average of nonstressed controls (set to $100 \%)$. Statistically significant differences: ${ }^{*} p<0.05$ versus nonstressed controls.

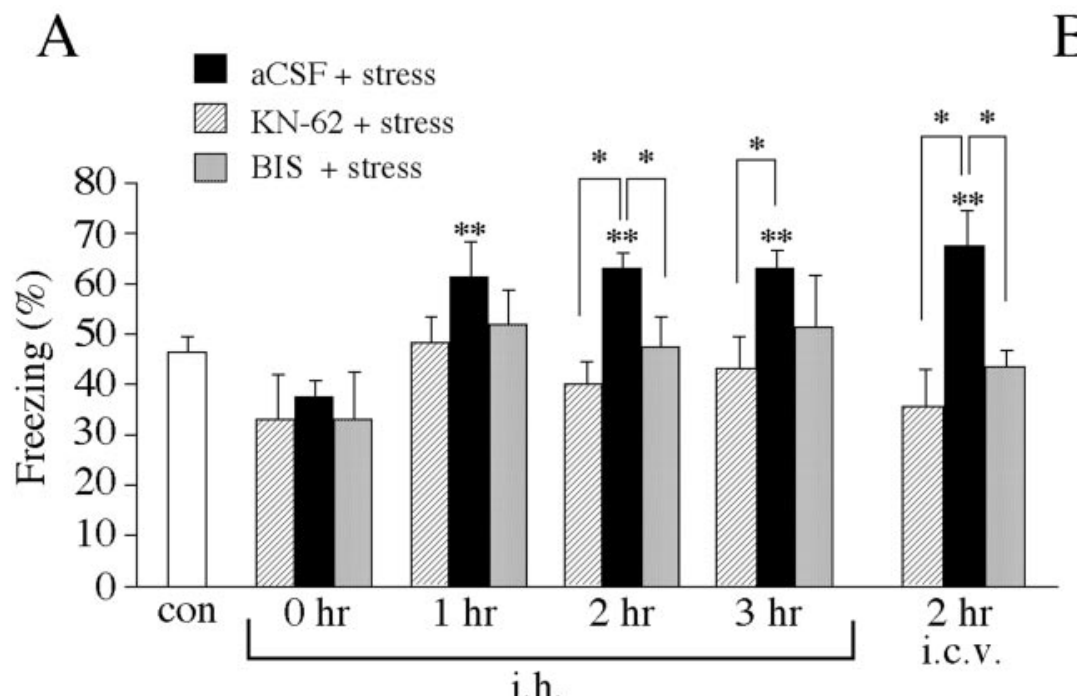

B

[Glu $\left.{ }^{11,16}\right]$ astr. + stress

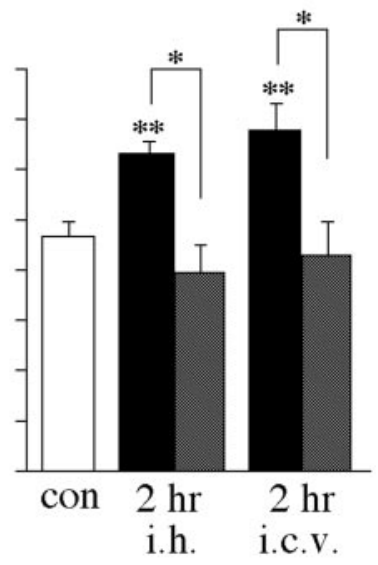

Figure 4. Inhibition of CRF receptors, PKC, and CaMKII in the dorsal hippocampus prevents stress-mediated enhancement of context-dependent fear conditioning. $A$, Mice were injected intrahippocampally (i.h.) or intracerebroventricularly (i.c.v.) with aCSF, KN-62, or BIS-I immediately before the start of the stress session and trained at several time points after the end of the stress session. $B$, Mice were injected intrahippocampally or intracerebroventricularly with [Glu ${ }^{11,16}$ ]astressin immediately before the stress session and trained $2 \mathrm{hr}$ after immobilization. Freezing was measured in the memory test performed $24 \mathrm{hr}$ after training. Statistically significant differences: * $p<0.05$ versus aCSF; $* * p<0.05$ versus control.

blot experiments showed that exposure of the animals to $1 \mathrm{hr}$ of immobilization resulted in elevated immunoreactivity of active, phosphorylated CaMKII, with a maximum at $2 \mathrm{hr}$ after the stress session (Fig. 3). However, intracerebroventricular injection of the selective CaMKII inhibitor KN-62 before the stress session did not significantly reduce PS-LTP persistence $(155 \pm 10 \% ; n=5)$ (Fig. $2 B$ ) compared with PS-LTP induced in slices from stressed animals (Fig. 2A).

\section{Acute stress and fear conditioning}

The previous experiments have shown that acute stress facilitated PS-LTP in the hippocampus and that this facilitation was prevented only by BIS-I and [Glu ${ }^{11,16}$ ]astressin but not by KN-62. In the next series of experiments, we investigated whether the same compounds exhibited effects on learning of conditioned fear. Thus, mice received bilateral aCSF intrahippocampal injections immediately before $1 \mathrm{hr}$ of immobilization and were trained at 0 , 1,2 , and $3 \mathrm{hr}$ after termination of the stress session. At $1 \mathrm{hr}(p<$ $0.01 ; n=11), 2 \mathrm{hr}(p<0.001 ; n=12)$, and $3 \mathrm{hr}(p<0.001 ; n=$ 10) after exposure to immobilization, contextual fear was signif- icantly enhanced compared with nonstressed controls $(n=30)$ (Fig. 4). Injection of KN-62 intrahippocampally before stress significantly reduced freezing $2 \mathrm{hr}(p<0.001 ; n=8)$ and $3 \mathrm{hr}$ $(p<0.01 ; n=5)$ after the end of the stress session compared with stressed, aCSF-injected mice (Fig. 4). Similarly, freezing was reduced $2 \mathrm{hr}$ after exposure to immobilization $(p<0.005 ; n=8)$ when KN-62 was injected intracerebroventricularly (Fig. 4). However, KN-62 injection alone (intrahippocampally) without exposing the animal to immobilization significantly reduced freezing $3 \mathrm{hr}$ after injection compared with nonstressed, aCSF-injected controls ( $p<0.001 ; n=5$; data not shown). Freezing was also significantly reduced $2 \mathrm{hr}$ after the stress session when mice were injected before stress with BIS-I intrahippocampally $(p<0.01 ; n=5)$ and intracerebroventricularly $(p<0.01 ; n=9)$ (Fig. 4). Likewise, [Glu ${ }^{11,16}$ ] astressin significantly reduced conditioned contextual fear $2 \mathrm{hr}$ after the end of immobilization when injected intrahippocampally ( $p<0.001 ; n=5$ ) and intracerebroventricularly ( $p<0.01 ; n=8$ ) compared with stressed, aCSFinjected mice. Both compounds, BIS-I and $\left[\mathrm{Glu}^{11,16}\right]$ astressin, had 
no significant effect on freezing when mice were injected intrahippocampally and intracerebroventricularly without immobilization (data not shown).

\section{DISCUSSION}

Recent behavioral studies have shown that stress (Conrad et al., 1999; Deak et al., 1999) and intracerebroventricular injection of h/rCRF (Radulovic et al., 1999) enhance, under defined conditions, contextual fear conditioning, which represents a hippocampus-dependent learning task in rats (Kim and Fanselow, 1992; Phillips and LeDoux, 1992; Holland and Bouton, 1999) and mice (Chen et al., 1996; Abel et al., 1997; Logue et al., 1997). At the same time, stress blocks hippocampal high-frequency stimulation (HFS)-induced LTP and facilitates long-term depression (Xu et al., 1997). In the present experiments, we found that activation of CRF receptors mediated the PS-LTP priming observed after acute stress in the CA1 area of the mouse hippocampus. CRF can be directly secreted from nerve terminals located in the hippocampus during exposure to stress. Specifically, numerous, large CRF-immunoreactive neurons have been found in the hippocampal CA1 and CA3 region (Swanson et al., 1983; Merchenthaler, 1984).

A similar priming effect has been observed after activation of group I metabotropic glutamate receptors (mGluRs). The mGluR agonist $1 S, 3 R$-aminocyclopentanedicarboxylic acid (ACPD) was found to facilitate the persistence of fEPSP-LTP in area CA1 of rat hippocampal slices (Cohen and Abraham, 1996; Cohen et al., 1999; Raymond et al., 2000). In contrast to ACPD, $\mathrm{h} / \mathrm{rCRF}$ did not significantly enhance STP.

It is important to note that in all of our electrophysiological experiments, brain slices were equilibrated in aCSF for at least 2-3 hr after slice preparation before PS-LTP was induced. Consequently, it appears that the mechanisms critical for PS-LTP priming either have a slow turnover rate or reveal high stability to be detectable in brain slices from stressed mice even hours after preparation. This assumption is also confirmed by the finding that bath-applied $\mathrm{h} / \mathrm{rCRF}$ was still effective at PS-LTP priming at least $2 \mathrm{hr}$ after washout (Blank and Nijholt, unpublished observations). Recently, it was shown that previous activity that generates protein synthesis-dependent LTP may also prime the persistence of LTP in a second input (Frey and Morris, 1997). Similarly, activation of group I mGluRs facilitates the persistence of LTP in area CA1 of rat hippocampal slices by triggering de novo protein synthesis from existing mRNA (Raymond et al., 2000). In the case of mGluR-mediated enhancement of LTP, the new proteins seem to be synthesized in close proximity to the activated synapses. This observation implies for our experiments that newly synthesized proteins would have to be preserved or protein synthesis would have to continue during equilibration of the slices in aCSF to still affect PS-LTP persistence several hours after slice preparation.

The capability of the PKC inhibitor BIS-I to prevent PS-LTP priming by $\mathrm{h} / \mathrm{rCRF}$ and stress is consistent with the described priming effect of group I mGluR activation, which can lead to the liberation of inositol triphosphate and to the subsequent activation of PKC in hippocampal slices (Cohen et al., 1998). Interestingly, the PKC inhibitor BIS-I prevented only $\mathrm{h} / \mathrm{rCRF}$-mediated priming when it was applied $1 \mathrm{hr}$ before administration of $\mathrm{h} / \mathrm{rCRF}$. BIS-I had no effect on PS-LTP persistence when applied to slices already primed after TBS. This finding contradicts the hypothesis that persistent activation of PKC underlies the ob- served PS-LTP maintenance (Colley et al., 1990; Wang and Feng, 1992).

On the basis of the observation that $\left[\mathrm{Glu}^{11,16}\right]$ astressin and BIS-I in combination with $\mathrm{h} / \mathrm{rCRF}$ or stress reduced STP in hippocampal slices, it appeared possible that hippocampal CRF receptors and PKC were tonically activated. In support of this hypothesis, activation of PKC has been shown to be involved in LTP induction in rat hippocampal CA1 cells (Hvalby et al., 1994). However, BIS-I and [Glu ${ }^{11,16}$ ] astressin exhibited no effect on STP or contextual fear conditioning when applied individually, findings that argue against a possible involvement of tonically active hippocampal CRF receptors or tonically active PKC. It seems notable that $\left[\mathrm{Glu}^{11,16}\right]$ astressin and BIS-I affected induction of PS-LTP only when neuronal activity was enhanced, but not under baseline conditions. However, in the presence of BIS-I or $\left[\mathrm{Glu}^{11,16}\right]$ astressin, only a limited enhancement of neuronal activity can be expected, which most likely generated only a modest elevation of intracellular $\mathrm{Ca}^{2+}$ concentrations. Low levels of $\mathrm{Ca}^{2+}$ favor the activation of protein phosphatases, which, in turn, would lower the probability of LTP induction (Mulkey et al., 1994; Kato et al., 1999).

In addition, our findings revealed that pharmacological inhibition of hippocampal CRF receptors and PKC impaired the observed stress-mediated learning enhancement. These data are consistent with previous observations indicating that the contextual learning impairment of DBA mice can be reversed by activation of hippocampal PKC as determined by the fearconditioning task (Fordyce et al., 1995).

In the present study, we found elevated levels of active CaMKII in the mouse CA1 area $2 \mathrm{hr}$ after exposure to immobilization. Injection of the selective CaMKII inhibitor KN-62 did not prevent the priming of PS-LTP persistence observed when hippocampal brain slices were prepared $2 \mathrm{hr}$ after the end of the stress session. Although CaMKII activity was increased at this time, there was no evidence that baseline synaptic transmission was altered. Conflicting data about the effects of CaMKII activation on basal synaptic transmission and LTP induction in the CA1 region of the hippocampus have been reported. For example, it was found that increasing CaMKII activity in CA1 neurons by viral transfection (Pettit et al., 1994) or by injection of the active enzyme (Lledo et al., 1995) results in an enhancement of synaptic transmission and impairment of LTP induction. Direct injection of a constitutively active form of CaMKII into postsynaptic CA1 neurons potentiates evoked EPSCs significantly within 15-30 min (Lledo et al., 1995). In contrast, in CaMKII-Asp ${ }^{286}$ transgenic mice expressing activated CaMKII, no change in basal synaptic transmission has been observed (Mayford et al., 1995). Nevertheless, transgenic expression of activated CaMKII eliminates LTP in the range of $5-10 \mathrm{~Hz}$ with no effect on LTP in response to 100 $\mathrm{Hz}$ of tetanus stimulation (Mayford et al., 1995). In previous experiments (Blank and Nijholt, unpublished observations), we found significant PS-LTP impairment in the CA1 area of stressed mice ( $2 \mathrm{hr}$ after the end of immobilization) when PS-LTP was induced with the standard $100 \mathrm{~Hz}$ HFS protocol, which produced saturating PS-LTP in control animals. At that time, we also found elevated CaMKII activity in the hippocampal CA1 area, as demonstrated in the present study. Our finding that the facilitatory effects of acute stress on hippocampus-dependent learning paralleled those of PS-LTP induced by TBS but not by HFS might be explained by the fact that the impact of GABAergic transmission on LTP expression is highly dependent on tetanization parameters (Chapman et al., 1998). However, reduced GABAer- 
gic inhibition would be expected to result in elevated basal synaptic transmission in brain slices of stressed animals. We did not observe such an effect. If acute stress already induces maximal LTP-like phenomena in the mouse hippocampus, strong stimulation of hippocampal brain slices would not be expected to produce additional LTP (Kim et al., 1996). Thus, the question may not be whether TBS instead of HFS is responsible for facilitation of LTP in brain slices obtained from stressed animals but rather whether to use weak LTP stimulation instead of a strong stimulation protocol. In support of this hypothesis, Cohen and Abraham (1996) described that activation of mGluRs only facilitates the induction of LTP induced by weak TBS but does not enhance LTP induced by strong stimulation.

LTP is the most extensively studied form of neuroplasticity and is widely believed to be the substrate for learning and memory (Bliss and Collingridge, 1993; Maren and Baudry, 1995; Bear and Abraham, 1996). However, a definitive linkage of LTP to learning or memory has not been achieved. Our data show a clear correlation between improved learning and facilitation of TBS-induced PS-LTP persistence, and both phenomena appeared to be PKCdependent. At the same time, inhibition of CaMKII activity prevented learning improvement without impairment of PS-LTP persistence. The performance in a hippocampus-dependent task was affected without interference with the long-lasting enhancement of hippocampal synaptic transmission. This result suggests that the underlying synaptic mechanisms of PS-LTP priming seem to be necessary, but not sufficient, for learning enhancement.

\section{REFERENCES}

Abel T, Nguyen PV, Barad M, Deuel TA, Kandel ER, Bourtchouladze R (1997) Genetic demonstration of a role for PKA in the late phase of LTP and in hippocampus-based long-term memory. Cell 88:615-626.

Abraham WC, Bear MF (1996) Metaplasticity: the plasticity of synaptic plasticity. Trends Neurosci 19:126-130.

Aldenhoff JB, Gruol DL, Rivier J, Vale W, Siggins GR (1983) Corticotropin-releasing factor decreases postburst hyperpolarizations and excites hippocampal neurons. Science 221:875-877.

Bear MF, Abraham WC (1996) Long-term depression in hippocampus. Annu Rev Neurosci 19:437-462.

Blanchard RJ, Blanchard DC (1969) Passive and active reactions to fear-eliciting stimuli. J Comp Physiol Psychol 68:129-135.

Bliss TV, Collingridge GL (1993) A synaptic model of memory: longterm potentiation in the hippocampus. Nature 361:31-39.

Bolles RC, Riley AL (1973) Freezing as an avoidance response: another look at the operant-respondent distinction. Learn Motiv 4:268-275.

Buwalda B, de Boer SF, Van Kalkeren AA, Koolhaas JM (1997) Physiological and behavioral effects of chronic intracerebroventricular infusion of corticotropin-releasing factor in the rat. Psychoneuroendocrinology 22:297-309.

Chalmers DT, Lovenberg TW, De Souza EB (1995) Localization of novel corticotropin-releasing factor receptor (CRFR2) mRNA expression to specific subcortical nuclei in rat brain: comparison with CRF1 receptor mRNA expression. J Neurosci 15:6340-6350.

Chang CP, Pearse RV, O'Connell S, Rosenfeld MG (1993) Identification of a seven transmembrane helix receptor for corticotropinreleasing factor and sauvagine in mammalian brain. Neuron 11:1187-1195.

Chapman CA, Perez Y, Lacaille JC (1998) Effects of GABA(A) inhibition on the expression of long-term potentiation in CA1 pyramidal cells are dependent on tetanization parameters. Hippocampus 8:289-298.

Chen C, Kim JJ, Thompson RF, Tonegawa S (1996) Hippocampal lesions impair contextual fear conditioning in two strains of mice. Behav Neurosci 110:1177-1180.

Cohen AS, Abraham WC (1996) Facilitation of long-term potentiation by prior activation of metabotropic glutamate receptors. J Neurophysiol 76:953-962.

Cohen AS, Raymond CR, Abraham WC (1998) Priming of long-term potentiation induced by activation of metabotropic glutamate receptors coupled to phospholipase C. Hippocampus 8:160-170.

Cohen AS, Coussens CM, Raymond CR, Abraham WC (1999) Longlasting increase in cellular excitability associated with the priming of LTP induction in rat hippocampus. J Neurophysiol 82:3139-3148.

Colley PA, Sheu FS, Routtenberg A (1990) Inhibition of protein kinase
C blocks two components of LTP persistence, leaving initial potentiation intact. J Neurosci 10:3353-3360.

Conrad CD, LeDoux JE, Magarinos AM, McEwen BS (1999) Repeated restraint stress facilitates fear conditioning independently of causing hippocampal CA3 dendritic atrophy. Behav Neurosci 113:902-913.

Deak T, Nguyen KT, Ehrlich AL, Watkins LR, Spencer RL, Maier SF, Licinio J, Wong ML, Chrousos GP, Webster E, Gold PW (1999) The impact of the nonpeptide corticotropin-releasing hormone antagonist antalarmin on behavioral and endocrine responses to stress. Endocrinology 140:79-86.

De Souza EB, Insel TR, Perrin MH, Rivier J, Vale WW, Kuhar MJ (1985) Corticotropin-releasing factor receptors are widely distributed within the rat central nervous system: an autoradiographic study. J Neurosci 5:3189-3203.

Eckart K, Radulovic J, Radulovic M, Jahn O, Blank T, Stiedl O, Spiess J (1999) Actions of CRF and its analogs. Curr Med Chem 6:1035-1053.

Eckart K, Jahn O, Radulovic J, Tezval H, van Werven L, Spiess J (2001) A single amino acid serves as an affinity switch between the receptor and the binding protein of corticotropin-releasing factor: implications for the design of agonists and antagonists. Proc Natl Acad Sci USA 98:11142-11147.

Fanselow MS, Bolles RC (1979) Naloxone and shock-elicited freezing in the rat. J Comp Physiol Psychol 93:736-744.

Fordyce DE, Clark VJ, Paylor R, Wehner JM (1995) Enhancement of hippocampally-mediated learning and protein kinase $\mathrm{C}$ activity by oxiracetam in learning-impaired DBA/2 mice. Brain Res 672:170-176.

Foy MR, Stanton ME, Levine S, Thompson RF (1987) Behavioral stress impairs long-term potentiation in rodent hippocampus. Behav Neural Biol 48:138-149.

Franklin KBJ, Paxinos G (1997) The mouse brain in stereotaxic coordinates. San Diego: Academic.

Frey U, Morris RGM (1997) Synaptic tagging and long-term potentiation. Nature 385:533-536.

Haug T, Storm JF (2000) Protein kinase A mediates the modulation of the slow $\mathrm{Ca}^{2+}$-dependent $\mathrm{K}^{+}$current, I(sAHP), by the neuropeptides CRF, VIP, and CGRP in hippocampal pyramidal neurons. J Neurophysiol 83:2071-2079.

Heinrichs SC, Menzaghi F, Merlo Pich E, Britton KT, Koob GF (1995) The role of CRF in behavioral aspects of stress. Ann NY Acad Sci 771:92-104.

Holahan MR, Kalin NH, Kelley AE (1997) Microinfusion of corticotropin-releasing factor into the nucleus accumbens shell results in increased behavioral arousal and oral motor activity. Psychopharmacology 130:189-196.

Holland PC, Bouton ME (1999) Hippocampus and context in classical conditioning. Curr Opin Neurobiol 9:195-202.

Hollrigel GS, Chen K, Baram TZ, Soltesz I (1998) The pro-convulsant actions of corticotropin-releasing hormone in the hippocampus of infant rats. Neuroscience 84:71-79.

Huang EP (1998) Synaptic plasticity: going through phases with LTP. Curr Biol 8:R350-R352.

Hvalby O, Hemmings Jr HC, Paulsen O, Czernik AJ, Nairn AC, Godfraind JM, Jensen V, Raastad M, Storm JF, Andersen P, Greengard P (1994) Specificity of protein kinase inhibitor peptides and induction of long-term potentiation. Proc Natl Acad Sci USA 91:4761-4765.

Kato K, Li ST, Zorumski CF (1999) Modulation of long-term potentiation induction in the hippocampus by $N$-methyl-D-aspartate-mediated presynaptic inhibition. Neuroscience 92:1261-1272.

Kim JJ, Fanselow MS (1992) Modality-specific retrograde amnesia of fear. Science 256:675-677.

Kim JJ, Yoon KS (1998) Stress: metaplastic effects in the hippocampus. Trends Neurosci 21:505-509.

Kim JJ, Foy MR, Thompson RF (1996) Behavioral stress modifies hippocampal plasticity through $N$-methyl-D-aspartate receptor activation. Proc Natl Acad Sci USA 93:4750-4753.

Koob GF, Heinrichs SC (1999) A role for corticotropin releasing factor and urocortin in behavioral responses to stressors. Brain Res 848:141-152.

Lee EH, Hung HC, Lu KT, Chen WH, Chen HY (1992) Protein synthesis in the hippocampus associated with memory facilitation by corticotropin-releasing factor in rats. Peptides 13:927-937.

Linthorst ACE, Flachskamm C, Hopkins SJ, Hoadley ME, Labeur MS, Holsboer F, Reul JMHM (1997) Long-term intracerebroventricular infusion of corticotropin-releasing hormone alters neuroendocrine, neurochemical, autonomic, behavioral, and cytokine responses to a systemic inflammatory challenge. J Neurosci 17:4448-4460.

Lledo PM, Hjelmstad GO, Mukherji S, Soderling TR, Malenka RC, Nicoll RA (1995) Calcium/calmodulin-dependent kinase II and longterm potentiation enhance synaptic transmission by the same mechanism. Proc Natl Acad Sci USA 92:11175-11179.

Logue SF, Paylor R, Wehner JM (1997) Hippocampal lesions cause learning deficits in inbred mice in the Morris water maze and conditioned-fear task. Behav Neurosci 111:104-113.

Malenka RC, Kauer JA, Perkel DJ, Mauk MD, Kelly PT, Nicoll RA, Waxham MN (1989) An essential role for postsynaptic calmodulin 
and protein kinase activity in long-term potentiation. Nature 340: $554-557$.

Malinow R, Schulman H, Tsien RW (1989) Inhibition of postsynaptic PKC or CaMKII blocks induction but not expression of LTP. Science 245:862-866.

Maren S, Baudry M (1995) Properties and mechanisms of long-term synaptic plasticity in the mammalian brain: relationships to learning and memory. Neurobiol Learn Mem 63:1-18.

Mayford M, Wang J, Kandel ER, O’Dell TJ (1995) CaMKII regulates the frequency-response function of hippocampal synapses for the production of both LTD and LTP. Cell 81:891-904.

Merchenthaler I (1984) Corticotropin releasing factor (CRF)-like immunoreactivity in the rat central nervous system: extrahypothalamic distribution. Peptides 5:53-69.

Mulkey RM, Endo S, Shenolikar S, Malenka RC (1994) Involvement of a calcineurin/inhibitor-1 phosphatase cascade in hippocampal longterm depression. Nature 369:486-488.

Pettit DL, Perlman S, Malinow R (1994) Potentiated transmission and prevention of further LTP by increased CaMKII activity in postsynaptic hippocampal slice neurons. Science 266:1881-1885.

Phillips RG, LeDoux JE (1992) Differential contribution of amygdala and hippocampus to cued and contextual fear conditioning. Behav Neurosci 106:274-285.

Phillips RG, LeDoux JE (1994) Lesions of the dorsal hippocampal formation interfere with background but not foreground contextual fear conditioning. Learn Mem 1:34-44.

Potter E, Sutton S, Donaldson C, Chen R, Perrin M, Lewis K, Sawchenko PE, Vale W (1994) Distribution of corticotropin-releasing factor receptor mRNA expression in the rat brain and pituitary. Proc Natl Acad Sci USA 91:8777-8781.

Radulovic J, Rühmann A, Liepold T, Spiess J (1999) Modulation of learning and anxiety by corticotropin-releasing factor (CRF) and stress: differential roles of CRF receptors 1 and 2. J Neurosci 19:5016-5025.

Raymond CR, Thompson V, Tate WP, Abraham WC (2000) Metabotropic glutamate receptors trigger homosynaptic protein synthesis to prolong long-term potentiation. J Neurosci 20:969-976.

Rühmann A, Köpke AK, Dautzenberg FM, Spiess J (1996) Synthesis and characterization of a photoactivatable analog of corticotropin- releasing factor for specific receptor labeling. Proc Natl Acad Sci USA 93:10609-10613.

Smith MA, Makino S, Kvetnansky R, Post RM (1995) Stress and glucocorticoids affect the expression of brain-derived neurotrophic factor and neurotrophin-3 mRNAs in the hippocampus. J Neurosci 15:1961-1970.

Spiess J, Rivier J, Rivier C, Vale W (1981) Primary structure of corticotropin-releasing factor from ovine hypothalamus. Proc Natl Acad Sci USA 78:6517-6521.

Stiedl O, Birkenfeld K, Palve M, Spiess J (2000) Impairment of conditioned contextual fear of $\mathrm{C} 57 \mathrm{BL} / 6 \mathrm{~J}$ mice by intracerebral injections of the NMDA receptor antagonist APV. Behav Brain Res 116:157-168.

Swanson LW, Sawchenko PE, Rivier J, Vale WW (1983) Organization of ovine corticotropin-releasing factor immunoreactive cells and fibers in the rat brain: an immunohistochemical study. Neuroendocrinology 36:165-186.

Toullec D, Pianetti P, Coste H, Bellevergue P, Grand-Perret T, Ajakane M, Baudet V, Boissin P, Boursier E, Loriolle F, Duhamel L, Charon D Kirilovsky J (1991) The bisindolylmaleimide GF $109203 \mathrm{X}$ is a potent and selective inhibitor of protein kinase C. J Biol Chem 266:15771-15781.

Turnbull AV, Rivier C (1997) Corticotropin-releasing factor (CRF) and endocrine responses to stress: CRF receptors, binding protein, and related peptides. Proc Soc Exp Biol Med 215:1-10.

Vale W, Spiess J, Rivier C, Rivier J (1981) Characterization of a 41residue ovine hypothalamic peptide that stimulates secretion of corticotropin and $\beta$-endorphin. Science 213:1394-1397.

Wang HL, Wayner MJ, Chai CY, Lee EH (1998) Corticotropinreleasing factor produces a long-lasting enhancement of synaptic efficacy in the hippocampus. Eur J Neurosci 10:3428-3437.

Wang HL, Tsai LY, Lee EH (2000) Corticotropin-releasing factor produces a protein synthesis-dependent long-lasting potentiation in dentate gyrus neurons. J Neurophysiol 83:343-349.

Wang JH, Feng DP (1992) Postsynaptic protein kinase C essential to induction and maintenance of long-term potentiation in the hippocampal CA1 region. Proc Natl Acad Sci USA 89:2576-2580.

Xu L, Anwyl R, Rowan MJ (1997) Behavioural stress facilitates the induction of long-term depression in the hippocampus. Nature 387:497500 . 